\title{
SRGAP3/RAF1 Fusion Gene
}

National Cancer Institute

\section{Source}

National Cancer Institute. SRGAP3/RAF1 Fusion Gene. NCI Thesaurus. Code C99710.

A fusion gene ( $\sim 3.5 \mathrm{~kb})$ that results from a tandem duplication at chromosome 3p25 which fuses exon 12 of the SRGAP3 gene to exon 10 of the RAF1 gene. This fusion is associated with pilocytic astrocytoma. 